\title{
Challenges Associated with Quality of Soda Ash, Abijata Lake, Central Main Ethiopian Rift, Ethiopia
}

\section{Berihu Gidey and Bheemalingeswara Konka*}

School of Earth Science, CNCS, P.O. Box 231, Mekelle University, Mekelle, Ethiopia (*kbheema2006@gmail.com).

\begin{abstract}
Abijata-Shalla Soda Ash Share Company in the central Main Ethiopian Rift is producing soda ash $\left(\mathrm{Na}_{2} \mathrm{CO}_{3}\right)$ by evaporating brine water from Abijata Lake. A study was undertaken to assess the challenges associated with the mining practices and quality of soda ash. Presently, 5000t of soda ash is produced annually with a grade of about $90 \%$ against the expected 20,000t with $97 \%$ grade. During fieldwork, a geological map is prepared and collected soil, trona, soda ash and water samples for chemical analysis. Water samples were collected from the lake and from different evaporation ponds. Soil samples were collected around the ponds and soda ash samples from the processing plant. All the samples were analyzed for major cations and anions in addition to $\mathrm{pH}$ and other parameters. The field and laboratory data suggest that the mining method, pond design, and the timing of transfer of brine water from one pond to another are the major challenges that are affecting the quality of soda ash. New pond design is suggested with minor modification to the existing design which is expected to increase the grade close to $97 \%$ $\mathrm{Na}_{2} \mathrm{CO}_{3}$.
\end{abstract}

Keywords: Abijata-Shalla Lakes, Brine water, Evaporation, Trona, Soda Ash, Ethiopia.

\section{INTRODUCTION}

Soda ash $\left(\mathrm{Na}_{2} \mathrm{CO}_{3}\right)$, also known as trona, is one of the industrial minerals mainly used in glass industry. African continent hosts numerous sodium carbonate occurrences. They are scattered throughout the continent and vary in size from small isolated to large deposits. Majority of them are found in East African Rift Valley (Garrett, 1992). Ethiopia also has several sodium carbonate- bearing lakes such as Abijata, Shalla and Chitu in central Main Ethiopian Rift Valley with minable reserves; and Medago, Dillo and Alsedo lakes in Sidamo region in south Ethiopia with small reserves (Geological Survey of Ethiopia, 2006). At present, soda ash mining is being carried out by Abijata-Shalla Soda Ash Share Company (ASSASC) using water from Abijata Lake. At present, it is the only company producing soda ash in Ethiopia. A pilot processing plant was established in 1989 by the Ethiopian Mineral Resource Development Corporation (EMRDC) in line with the agreement signed with Giulini Chemie $\mathrm{GmbH}$, a German-based company. It has been producing soda ash and related byproducts for local and foreign markets by evaporating brine water from Abijata Lake. 
The method involves mining of sodium carbonate-rich water (referred as brine water), from Abijata Lake and transferring into the artificially made set of ponds for evaporation and crystallization of trona (Fig 1). The basic principle involved in this process is the specific gravity of the brine which keeps changing with increasing evaporation and results in the crystallization of different minerals such as sodium chloride, sodium carbonate etc. based on the specific gravity. The trona thus crystallized at a particular stage is collected and processed. The order of deposition or crystallization of different salts is calcium carbonate, calcium sulphate, sodium carbonate, sodium chloride, magnesium sulfate, potassium chloride and magnesium chloride (Ralston et al., 2016). Precipitation begins when brine water specific gravity is about $1.2 \mathrm{~g} / \mathrm{cm}^{3}$. At this stage, suspended impurities such as sand, clay and the less soluble salts such as calcium carbonate, and calcium sulfate are removed. Others like sodium, magnesium and potassium salts still remain in solution and get separated in the later stages of evaporation. The brine is then transferred to another pond and evaporated to obtain sodium carbonate at $1.25 \mathrm{~g} / \mathrm{cm}^{3}$.

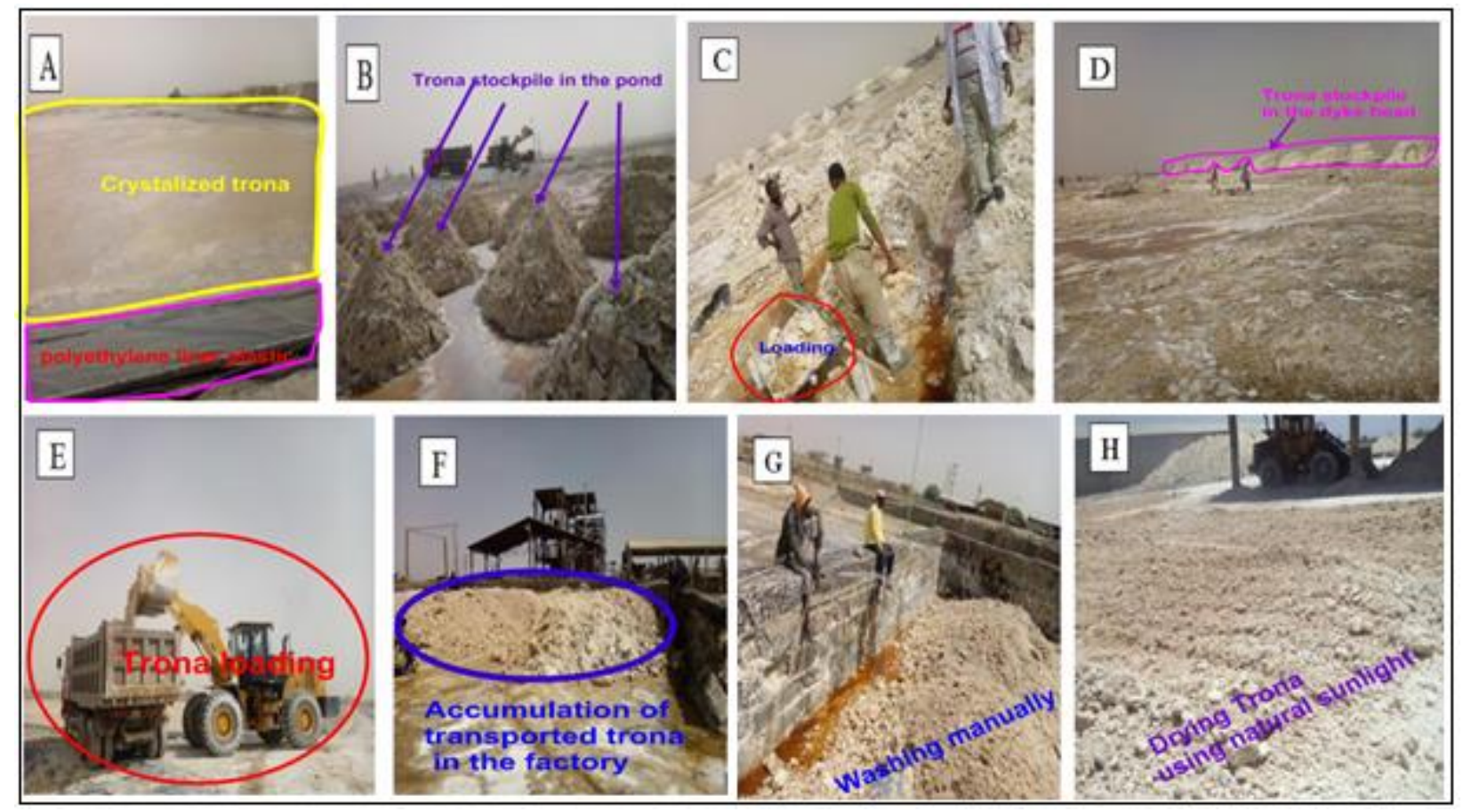

Figure 1. Photographs showing trona production process, starting from trona crystallization to the processing plant, A) crystalized trona, B) harvesting and stockpile trona in the pond, C) removing trona from the pond, D) accumulating trona in the dyke head, E) loading trona from the head dyke, F) piling (accumulating) trona for washing, G) washing trona manually by groundwater, and $\mathrm{H}$ ) drying washed trona by sunlight. 
Abijata-Shalla Soda Ash Mining Company has developed 24 ponds of 240 and $210 \mathrm{~m}^{3}$ sizes in the alluvial sediment. The ponds are referred as pre-concentration ponds, trona ponds, effluent ponds and salt ponds (Fig 1). The crystallized trona is harvested manually from the production ponds and piled on the dyke heads (boundaries of the pond) and transported to the washing area where it is washed with fresh groundwater to remove impurities like sediment, sodium chloride etc. and sent to the processing plant for further processing (Fig 1). All the ponds except one are lined with polyethylene plastic sheets to avoid loss of brine water into the ground by percolation and avoid contamination of trona with soil. The pond which is not lined with plastic sheet is used for waste disposal.

The estimated reserve of soda ash in both Abijata and Shalla Lakes is about $~ 380$ million tons. The company was planned to produce about 20,000 tons of soda ash per year in phase one and increase to 1 million tons per year of $97 \%$ grade in phase two (Tahal Consultancy of Engineers Ltd, 1987). However, at present, the company is producing less than 5000 tons per year with $<90 \%$ grade of sodium carbonate. Keeping this gap in view, a study was undertaken to assess the challenges associated with mining and quality of soda ash. The results are presented here.

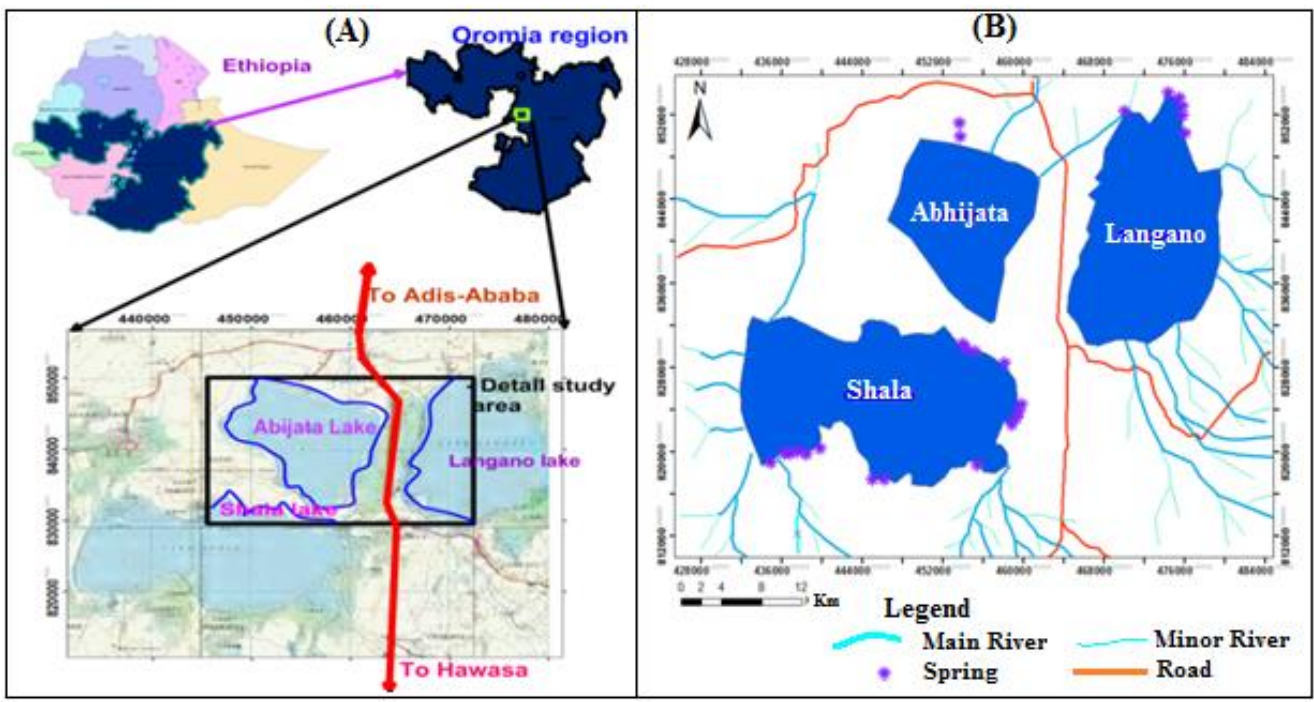

Figure 2. Map showing the location of the study area (A) accessibility map, (B) Lakes AbijataShala and Langano with drainage and spring water locations.

\subsection{The Study Area}

The study area lies in the Main Ethiopian Rift Valley near Abijata-Shalla National Park, $200 \mathrm{~km}$ south of Addis Ababa. It is geographically located between UTM coordinates of 445000- 
$475000 \mathrm{mE}$ and $830000-850000 \mathrm{mN}$ (Fig 2). It is accessible by asphalt road from Addis Ababa by asphalt road upto Shashamane and by gravel road about 15km, northwest of Shashamane.

\section{METHODOLOGY}

To achieve the objective of the study following methodology has been followed. It included detailed filed work and sampling and their analysis.

\subsection{Field Data Collection and Sampling}

Firstly, all available secondary data on geology, mining process, pond design and processing plant was collected prior to planning of fieldwork. A detailed fieldwork was conducted in and around the mining area and prepared a geological and structural map in the scale of 1:50,000 (Fig 3). Ten water samples, $500 \mathrm{ml}$ each, were collected from the Abijata Lake and different evaporation and crystallization ponds. Ten were analyzed at Mekelle University and six out of ten were analyzed at Company laboratory (Tables $1 \& 2$ ). Out of 10, one each is collected from Lakes Abijata, Shala, Langano and Ziway; one each from 2 springs; one each from water flowing channels (from lake to main pumping station, from pumping station to pond); and one from well near processing plant. Small open air channels about 2 feet wide and one feet deep are made in the ground to supply Lake Water by gravity to the main pumping station which is about $100 \mathrm{~m}$ from the water body. Water thus collected at pumping station is pumped to the ponds through the similar small open air channels. 11 solid samples, about $2 \mathrm{~kg}$ each, were collected from harvest trona (unwashed trona), washed trona, input trona, soda ash during processing, output soda ash, fine soda ash, effluent salt, waste discharge from the plant and soil from the banks of the ponds.

\subsection{Sample Preparation and Analysis}

All water samples were filtered using 0.45 micron filter paper before submitting to laboratory for analysis. The solid samples were crushed and grounded to produce fine powders. $20 \mathrm{~g}$ of the powder sample was transferred to $100 \mathrm{ml}$ beaker and added $50 \mathrm{ml}$ of distilled water and agitated for few minutes and kept overnight for dissolution of the powder samples. Then, the solutions were filtered and the aliquot was submitted for analysis.

Both the water samples and aliquots of solid samples analyzed for major cations and anions in two laboratories, ASSASC Company laboratory and Mekelle University hydrogeochemical laboratory using Atomic Absorption Spectrophotometer (AAS) for cation 
analysis, UV-spectrophotometer for anions and titration method for carbonate and bicarbonate analysis. All 10 samples were analyzed at Mekelle University and 6 of these samples were also analyzed at company for cross checking. Data is presented in tables 1 and 2.

\subsection{Pond Design}

The soda ash quality and production rate were observed in detail during mining and processing. The timing of transfer of brine water from one pond to another and related specific gravity were observed and noted that the quality of trona is primarily dependent on the timing of transfer and specific gravity of brine water. This led to the development of new pond design which can improve the quality.

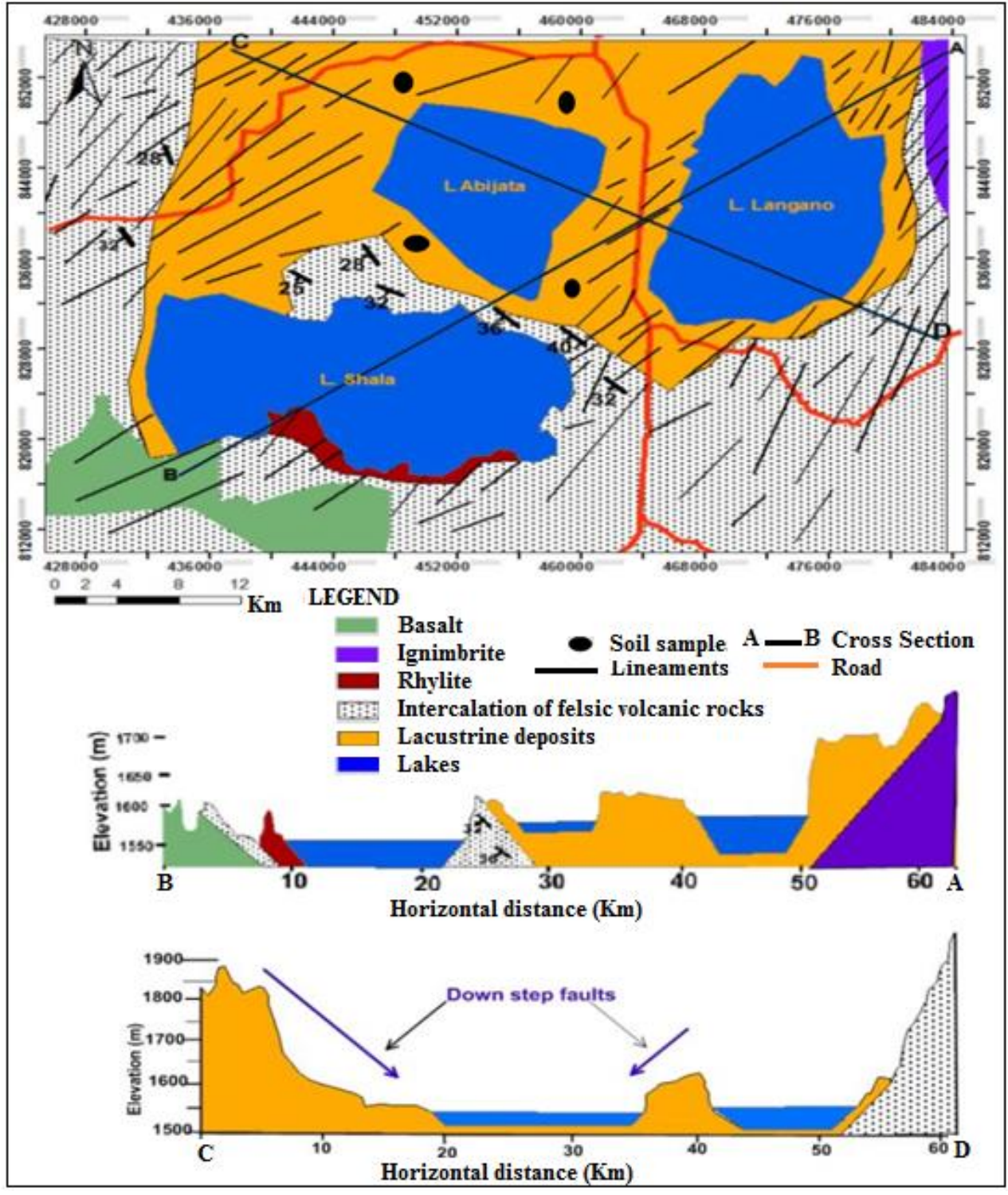

Figure 3. Geological map with cross-sections A-B and C-D. 


\section{GEOLOGY OF THE STUDY AREA}

The area is covered by different volcanic rocks and lacustrine sediments. The rocks include rhyolite, ignimbrite, un-welded tuffs, obsidian and basalt. They are exposed in the eastern and western escarpment of the central sector of the Main Ethiopian rift valley and southern part of the study area (Fig 3). Many lakes are present within the rift valley, such as Ziway, Awassa, Abijata, Shalla, Langano etc. These lakes together could have formed as a single huge lake during late Pleistocene period due to wet climatic conditions prevailed during that time (Mohr, 1971). The study area is affected by rift-related tectonics which resulted in the development of major and minor faults and joints (Fig 3). Hundreds of NNE trending parallel faults are formed by a line and volcanic centers along the rift floor close to the eastern escarpment and arranged in en-echelon fashion. The volcano-tectonic axis named as Wonji Fault Belt (WFB), is considered to be the current axis of crustal extension (Meyer et al., 1975; Morton et al., 1979).

\section{RESULTS}

\subsection{Water Sample Data}

Water samples from Abijata Lake show higher values for most of the parameters compared to Shalla and Langano Lakes (Table 1). Among Shalla and Langano, water from Shalla Lake shows relatively higher values for all the parameters. $\mathrm{pH}$ is varying from 8.86 to 9.93 ; temperature, 32 to $33.7^{\circ} \mathrm{C}$ except for one (spring) which shows $63.2^{\circ} \mathrm{C}$; specific gravity, 0.94 to 1.052 ; alkalinity, 0.74 to 3.61 ; sodium carbonate, 0.42 to $2.85 \%$; sodium bicarbonate, 0.38 to $1.24 \%$; and sodium chloride, 0.28 to $1.56 \%$.

Table 1. Chemical analysis results of water samples (Company Laboratory, Feb, 2016).

\begin{tabular}{|l|l|l|l|l|l|l|l|l|}
\hline S.No & Sample & $\boldsymbol{p H}$ & $\boldsymbol{T}\left({ }^{\boldsymbol{o}} \mathbf{C}\right)$ & Sp. Gravity & $\% \mathbf{N a}_{2} \mathbf{C O}_{3}$ & $\%$ NaHCO & $\%$ NaCl & $\begin{array}{l}\text { Total } \\
\text { alkalinity }\end{array}$ \\
\hline 1 & Abijata Lake & 9.93 & 32.4 & 1.052 & 2.85 & 1.24 & 1.56 & 3.61 \\
\hline 2 & Abijata Lake** & 9.97 & 33.2 & 1.045 & 2.62 & 1.21 & 1.52 & 3.48 \\
\hline 3 & Abijata Lake \# & 9.8 & 33.7 & 1.041 & 2.19 & 1.07 & 1.17 & 2.86 \\
\hline 4 & Shalla Lake & 9.67 & 32.1 & 1.04 & 0.84 & 0.69 & 0.62 & 1.28 \\
\hline 5 & Shalla Lake\% & 9.03 & 63.2 & 1.00 & 0.62 & 0.38 & 0.28 & 0.93 \\
\hline 6 & Langano Lake & 8.86 & 32.0 & 0.94 & 0.42 & 0.50 & 0.37 & 0.74 \\
\hline
\end{tabular}

Note: ${ }^{* *}$ from small channels after pumping;

\# from main pumping station;

$\%$ from hot spring water). 
Table 2. The analysis result of water samples (in $\mathrm{mg} / \mathrm{L}$ except EC which is in $\mu \mathrm{S} / \mathrm{cm}$ )(data from Mekelle University Hydrogeochemical laboratory, April 2016) (Note: * flowing water from Lake; ** from small channels after pumping; \# from main pumping station; \#\# Spring water; @ well water near processing plant; \% hot spring water; NA = not analyzed)).

\begin{tabular}{|c|c|c|c|c|c|c|c|c|c|c|c|c|}
\hline S. No & Water samples & $\mathrm{Na}^{+}$ & $\mathrm{Ca}^{2+}$ & $\mathrm{Mg}^{2+}$ & $K^{+}$ & $\mathrm{Cl}^{-}$ & $F^{-}$ & $\mathrm{CO}_{3}^{-2}$ & $\mathrm{HCO}_{3}^{-}$ & $E C$ & TDS & $p H$ \\
\hline 1 & Lake Ziway & 79 & 13 & 7 & 27 & 76 & 0.08 & 17.32 & 457.5 & 802 & 571.9 & 8.92 \\
\hline 2 & Lake Langano & 129 & 8 & 0 & 29 & 129 & 0.09 & 33.12 & 994.3 & 62800 & 44783 & 8.86 \\
\hline 3 & Lake Abijata & 199 & 8 & 0 & 22 & 195 & 0.09 & 11243 & 50906 & 64500 & 45995 & 9.93 \\
\hline 4 & Abijata Lake* & 199 & 8 & 0 & 33 & 196 & 0.07 & 10397 & 49578 & 58400 & 41645 & 9.97 \\
\hline 5 & Abijata Lake** & 200 & 8 & 0 & 34 & 196 & 0.07 & 8609.8 & 35781 & 55400 & 39506 & 9.98 \\
\hline 6 & Abijata Lake & 200 & 8 & 0 & 28 & 192 & 0.07 & 6117.1 & 32096 & 49400 & 35227 & 9.8 \\
\hline 7 & Abijata Lake ${ }^{\# \#}$ & 183 & 9 & 29 & 33 & 181 & 0.06 & 461.62 & 4666 & 9840 & 7017 & 9.4 \\
\hline 8 & Abijata Lake ${ }^{@}$ & 147 & 8 & 1 & 32 & 162 & 0.05 & 194.53 & 2885 & 5860 & 4178 & 9.2 \\
\hline 9 & Lake Shalla & NA & 8 & 0 & 31 & 193 & 0.04 & 2716.4 & 16514 & 20600 & 14690 & 9.67 \\
\hline 10 & Lake Shalla\% & 153 & 8 & 0 & 15 & 152 & 0.06 & 244.77 & 1488 & 3560 & 2538 & 9.03 \\
\hline
\end{tabular}

Water samples data obtained from the Company and Mekelle University (Table 1 \& 2) indicate the same that sodium content is relatively higher in Abijata Lake compared to other Lakes. Sodium dominates among cations and bicarbonate among anions. Chloride among anions shows abundance after carbonate and fluorine but much lower compared to carbonate. Potassium among cations shows abundance after sodium but much lower compared to sodium. Negligible values are noted for magnesium (Table 2). Interestingly, bicarbonate dominates among anions and sodium among cations, sodium carbonate values are higher $(2.85 \%)$ compared to sodium bicarbonate $(1.24 \%)$.

\subsection{Solid Sample Data}

Samples were analyzed at both Company and Mekelle University laboratories and the data is given in tables 3 and 4. Data indicate the quality of trona at crystallization and different stages of processing including final recovery. Grade of soda ash produced by the company collected at final stage in the processing plant after washing etc, is about 90\%. Quality of trona is improved from about $35 \%$ from crystallization stage (input trona) to $90 \%$ (Table 3). At the same time, significant values for carbonate and bicarbonate for the sample from waste disposal clearly indicates the inefficiency of the processing method and loss of soda ash during processing (Table 4). Analysis of soil sample, collected as a reference near the evaporation ponds, shows relatively much lower values for bicarbonate, carbonate and sodium compared to the samples from crystallization ponds (Table 4). 
Table 3. Chemical analysis results of solid samples (Company laboratory, 2016).

\begin{tabular}{|l|l|l|l|l|l|}
\hline $\mathbf{S . ~ N o}$ & Sample type & $\mathrm{Na}_{2} \mathrm{CO}_{3}(\%)$ & $\mathrm{NaHCO}_{3}(\%)$ & $\mathbf{N a C l ~ ( \% )}$ & Total alkalinity \\
\hline 1 & Unwashed trona & 34.31 & 23.99 & 5.72 & 49.4 \\
\hline 2 & Washed trona & 35.06 & 23.65 & 1.71 & 50 \\
\hline 3 & Input trona & 35.7 & 21.89 & 1.73 & 49.5 \\
\hline 4 & In-process soda ash & 89.73 & 1.62 & 3.21 & 90.8 \\
\hline 5 & Output soda ash & 89.43 & 1.61 & 3.32 & 90.4 \\
\hline 6 & Fine soda ash & 89.45 & 1.61 & 3.34 & 90.5 \\
\hline
\end{tabular}

Table 4. Chemical data $(\mathrm{mg} / \mathrm{L})$ of solid samples (Mekelle University Hydrogeochemical laboratory, April 2016).

\begin{tabular}{|l|l|l|l|l|l|l|l|l|l|}
\hline $\mathbf{S .} \boldsymbol{N o}$ & Samples & $\mathbf{N a}^{+}$ & $\boldsymbol{C a}^{2+}$ & $\mathbf{M g}^{2+}$ & $\boldsymbol{K}^{+}$ & $\boldsymbol{C l}^{-}$ & $\boldsymbol{F}^{-}$ & $\boldsymbol{C O}_{3}^{-2}$ & $\mathbf{H C O}_{3}^{-}$ \\
\hline 1 & Effluent salt & 215 & 137 & 4 & 5.5 & 198 & 0.05 & 924,996 & $2,819,001.7$ \\
\hline 2 & Trona & 221 & 139 & 4 & 3.6 & 156 & 0.07 & $4,630,881.6$ & $10,565,373.9$ \\
\hline 3 & Soda Ash & 229 & 143 & 3 & 4.8 & 132 & 0.08 & $12,869,004$ & $26,657,361.7$ \\
\hline 4 & Waste discharge & 213 & 163 & 9 & 3 & 128 & 0.06 & $673,855.4$ & $4,802,977.6$ \\
\hline 5 & Soil sample & 10 & 334 & 12 & 6.3 & 8.6 & 0.09 & 2.8 & 231.8 \\
\hline
\end{tabular}

\section{DISCUSSION}

\subsection{Soda Ash Extraction Method and Its Quality}

The soda ash extraction method adopted by the company is quite simple. It involves pumping of brine water from Abijata Lake to the artificially prepared ponds and exposing it to sun light to facilitate evaporation. But, this method suffers from i) addition of dust by winds during crystallization, ii) dependency on sunlight restricts mining operations to summer season; and iii) dilution of Lake water during monsoon restricts mining operations; and iv) low production.

Table 5. Soda ash and other related salts produced by different countries $(\%)($ Note: $*=$ Metal Bulletin Ltd., London, 1980; ** = Present study).

\begin{tabular}{|l|l|l|l|l|l|}
\hline S. No & Composition & $\begin{array}{l}\text { Wyoming Natural } \\
\text { Trona }(\text { USA) }\end{array}$ & $\begin{array}{l}\text { Searles Lake Natural } \\
\text { Trona }(\text { USA) } *\end{array}$ & $\begin{array}{l}\text { Lake Magadi } \\
\text { Trona }(\text { Kenya) }\end{array}$ & $\begin{array}{l}\text { Lake Abijata } \\
(\text { Ethiopia)*** }\end{array}$ \\
\hline 1 & $\mathrm{Na}_{2} \mathrm{CO}_{3}$ & $\mathbf{9 9 . 8}$ & $\mathbf{9 9 . 6}$ & $\mathbf{9 7 . 3 0}$ & $\mathbf{8 9 . 4 5}$ \\
\hline 2 & $\mathrm{NaCl}$ & 0.01 & 0.20 & 0.43 & 3.34 \\
\hline 3 & $\mathrm{Na}_{2} \mathrm{SO}_{4}$ & 0.08 & 0.15 & 0.35 & 0.06 \\
\hline 4 & $\mathrm{Fe}_{2} \mathrm{O}_{3}$ & 0.001 & 0.0014 & 0.02 & - \\
\hline 5 & $\mathrm{Na}_{2} \mathrm{~B}_{4} \mathrm{O}_{7}$ & - & 0.007 & - & 3.5 \\
\hline 6 & $\mathrm{NaF}_{7}$ & - & - & 0.90 & - \\
\hline $\mathrm{NaHCO}_{3}$ & - & - & 0.40 & 1.61 \\
\hline
\end{tabular}

Even though the percentage of sodium carbonate increases from unwashed trona $(34.3 \%)$ to final soda ash product $(89.45 \%)$ (Table 3$)$, this quality is low as compared with other countries 
and expected grade of about $97 \%$. Soda ash produced by Abijata soda ash factory is of poor/low quality as compared with the other soda ash producing countries (Table 5).

\subsection{Factors affecting Quality and Quantity}

\subsubsection{Dilution}

Lake water is transported by gravity through small channels of about 2 feet wide and 1 feet deep prepared in the ground. During transportation, the water is getting diluted due to mixing of spring water. This is clearly indicated by the decreasing $\mathrm{Na}_{2} \mathrm{CO}_{3}$ concentrations in water from Lake to the main pumping station i.e. $2.85 \%$ to $2.18 \%$ (Table 1). Spring water is less alkaline compared to Lake water (Table 2) and dilutes the lake water along 100-200m from Lake to main pumping station and 1500 to $2000 \mathrm{~m}$ from main pumping station to the evaporation pond. However, as springs are randomly distributed, dilution effect is not uniform.

\subsubsection{Leakage}

The channels are made in the alluvial soil for water transportation. The channels being open and in soil, cracks developed in the side walls of the channels are causing leakage of water. Apart from this, the damage by the grazing animals affect the flow of water. Thus, subsurface water percolation is affecting the amount of water that supposed to reach the evaporation ponds.

\subsubsection{Dust}

Channels and ponds being open, considerable amount of dust added during windy season to the transporting Lake Water and ponds is affecting crystallization process and quality of trona.

\subsubsection{Distance}

Increasing distance between lake water and ponds with time due to decreasing water levels in the Lake, is increasing the cost of pumping and transportation problems i.e. dilution and dust.

\subsubsection{Climate}

Evaporation being dependent on natural sunlight, the time to achieve required brine specific gravity is variable. It is further affected by day and night temperatures. This is causing problem to achieve exact specific gravity for crystallization process and also for shifting brine water from one pond to another. In addition, mining operations being restricted to dry season from midSeptember to June of every year, it will affect the production.

\subsubsection{Timing of Transfer of Brine Water}

Transfer of brine water is based specific gravity and concentration of water. Under saturation or supersaturation will affect the process. If transfer is done before reaching the optimum range of 
specific gravity then it will carry impurities (silica, sulphate and fluorides) to the trona pond. If done after reaching optimum range, trona may be lost.

\subsubsection{Contamination}

Growth of algae in the lake and transfer of water together with algae to the evaporation ponds affects the quality of trona. It is one of the impurities that impart different colors to trona. Mixing of soil during handling and transportation of trona from pond to the processing plant is also affecting the quality of soda ash. The polyethylene plastic liners get damaged with time due to exposure to sun and during trona harvesting operations. This is resulting in brine losses by leakage and mixing of soil with harvest pond trona.

In addition to the quality problem, the rate of production is also low, producing around 5000 t/year against proposed one million tons (Tahal consulting of engineers Ltd, 1987). Some of the reasons for low production are: i) efficiency of the processing plant mainly accessories problem; ii) relatively fast reduction of Abijata Lake water level with time (may have structural control); iii) increasing distance from lake water and ponds increasing the costs; and iv) evaporation ponds design and lake water supply needs to be modified to increase the production.

\subsection{Existing Pond Design and Quality of Trona}

Designing of the evaporation ponds and timing of transfer of brine water from pre-concentration pond to trona pond; from trona pond to effluent pond plays an important role in trona quality. Transfer of brine water if not done properly, it will bring impurities if transferred early or causes formation of sodium chloride (referred as deca hydrate "Deca Point") if delayed. As a result the quality is affected. To improve this, understanding of the effect of minor specific gravity changes on crystallization of salts like sodium chloride and concentration range of brine water is important. Presently, the specifications followed by the Company are given in table 6. Based on these specifications the pond design is prepared (Fig 4).

Table 6. The specifications of raw materials at different stages of the existing ponds design and harvested trona (ASSASCO, 2015).

\begin{tabular}{|l|l|l|l|l|l|}
\hline $\begin{array}{l}\mathbf{S} . \\
\mathbf{N o}\end{array}$ & Sample type & $\begin{array}{l}\text { Specific gravity } \\
\left(\mathbf{g} / \mathbf{c m}^{3}\right)\end{array}$ & $\begin{array}{l}\mathrm{Na}_{2} \mathrm{CO}_{3} \\
(\%)\end{array}$ & $\begin{array}{l}\mathrm{NaHCO}_{3} \\
(\%)\end{array}$ & $\begin{array}{l}\mathbf{N a C l} \\
(\%)\end{array}$ \\
\hline 1 & $\begin{array}{l}\text { Discharge from pre-concentration to } \\
\text { production pond }\end{array}$ & $1.18-1.22$ & 10.5 & 3.3 & 2.4 \\
\hline 2 & Discharge from trona pond to effluent pond & $1.22-1.256$ & 14.12 & 1.04 & 12.5 \\
\hline 3 & Discharge from effluent pond to salt ponds & $1.256-1.31$ & 12.9 & 0.29 & 13.2 \\
\hline
\end{tabular}




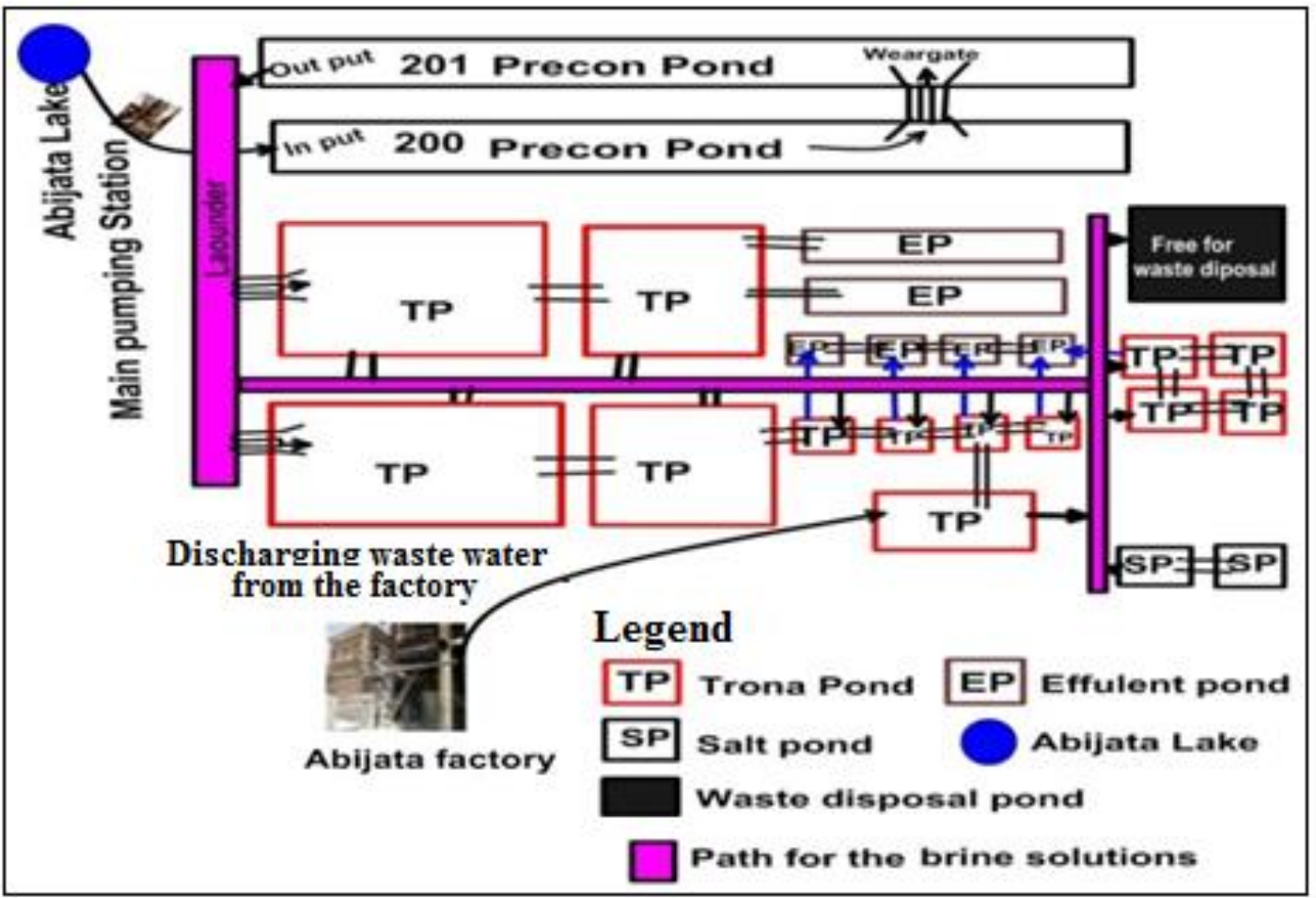

Figure 4. Pond design of the Company (ASSASCO, 2015).

Among various factors that are affecting the quality of trona, the existing Abijata pond design with reference to specific gravity of brine water and concentration of water during transfer from one pond to another (pre-concentration pond to production pond and production pond to effluent ponds) is considered most significant. Analytical data (Tables 1-4) amply suggest that less soluble and suspended material such as clay, silica, calcium sulphate are decreasing from pre-concentration pond to trona and effluent ponds while concentration of sodium chloride is increasing. This is one of the critical factors affecting the quality of soda ash. This factor combined with processing problems makes the quality of Ethiopian (Abijata) soda ash inferior in terms of having higher amounts of $\mathrm{NaCl}$ compared to other soda ash supplying countries (Table 5). Apart from $\mathrm{NaCl}$, two factors that affect soda ash quality are impurities in the pre-concentration pond and dust. Keeping this in view, a new pond design is suggested by rearranging the transfer time in accordance with specific gravity and concentration of brine water (Fig 5).

\subsection{Suggested Pond Design}

In the new pond design additional ponds are suggested to produce two types of trona, high quality trona (HQT) with $\sim 97 \% \mathrm{Na}_{2} \mathrm{CO}_{3}$ and normal quality trona (NQT) with $\sim 90 \% \mathrm{Na}_{2} \mathrm{CO}_{3}$ 
(Fig 5). This is done by re-arranging/improving the specific gravity and concentration range during transfer of brine water from one pond to another.

Table 7. The specifications needed at different stages in the new ponds design.

\begin{tabular}{|c|c|c|c|c|c|}
\hline S.No & Sample type & $\begin{array}{l}\text { Specific gravity } \\
\left({\left.\mathrm{g} / \mathrm{cm}^{3}\right)}^{3}\right.\end{array}$ & $\begin{array}{l}\mathrm{Na}_{2} \mathrm{CO}_{3} \\
(\%)\end{array}$ & $\begin{array}{l}\mathrm{NaHCO}_{3} \\
(\%)\end{array}$ & $\begin{array}{l}\mathrm{NaCl} \\
(\%)\end{array}$ \\
\hline 1 & $\begin{array}{l}\text { Transfer from pre-concentration pond to } 1^{\text {st }} \\
\text { column normal trona production pond (NT). }\end{array}$ & $1.18-1.215$ & 9.5 & 3.5 & 1.8 \\
\hline 2 & $\begin{array}{l}\text { Transferring from } 1^{\text {st }} \text { column NTP to High } \\
\text { Quality Trona production pond (HQT). }\end{array}$ & $1.215-1.225$ & 14.0 & 2.5 & 2.2 \\
\hline 3 & $\begin{array}{l}\text { Transferring from High Quality Trona } \\
\text { production pond (HQT) to } 3^{\text {rd }} \text { column NT. }\end{array}$ & $1.225-1.235$ & 12.5 & 2.0 & 3.2 \\
\hline 4 & $\begin{array}{l}\text { Transferring from } 3^{\text {rd }} \text { column NTP to } \\
\text { effluent pond. }\end{array}$ & $1.235-1.26$ & 13.0 & 1.0 & 12.5 \\
\hline 5 & Transferring from effluent salt to salt pond & $1.26-1.31$ & 10.5 & 0.3 & 15.0 \\
\hline
\end{tabular}

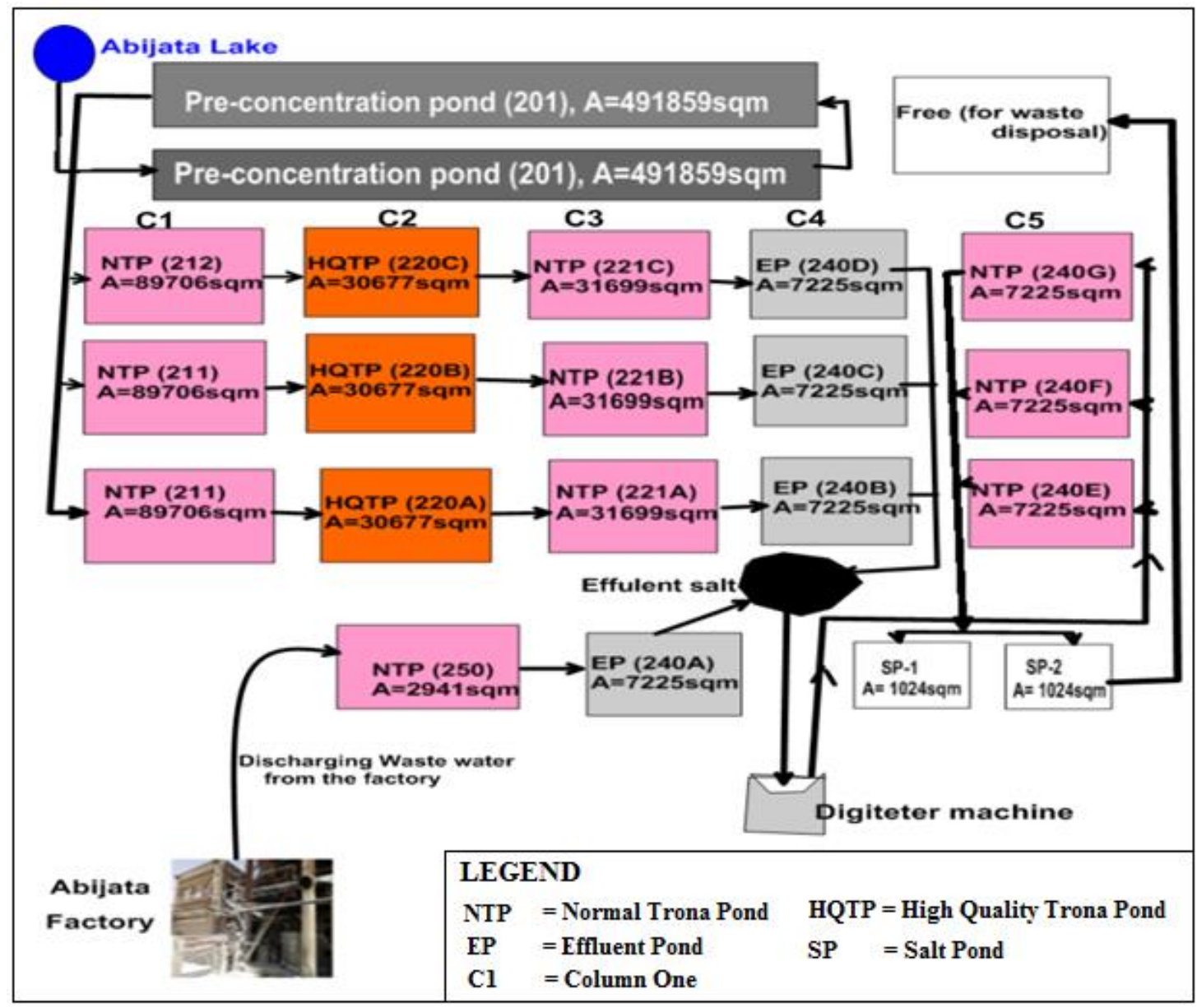

Figure 5. New pond design showing the processing from pre-concentration pond up to the trona production pond and the recycling of the factory's discharge waste water. 
The new design is preferable because it helps in maximum removal of impurities and $\mathrm{NaCl}$. Appropriate specifications required to achieve this are suggested (Table 7). In the existing pond design (Fig 4) only one type of trona is possible and having only one trona pond is affecting from both sides i.e. transfer from pre-concentration pond and transfer to effluent pond. The new design tries to address this, by adding new ponds and re-arranging the brine water transfer. The ponds in the present design are named as columns C1 to C5 (Fig 5).

\subsubsection{Column One (C1) Trona Pond}

This pond is to crystalize normal trona directly coming from the pre-concentration pond at a specific gravity range of $1.215-1.225 \mathrm{~g} / \mathrm{cm}^{3}$. This pond will receive brine after settlement of impurities in pre-concentration pond and also facilitates further settlement of impurities if any and transfer brine water to the next column (C2) for the crystallization of high quality trona.

\subsubsection{Column Two (C2) Trona Pond}

This pond is used for high quality trona by maintaining specific gravity range of 1.225$1.235 \mathrm{~g} / \mathrm{cm}^{3}$. Here, the effect of impurities except that comes from dust will be less because they are already settled in the column one pond. Before the brine water reached $\mathrm{NaCl}$ crystallization stage it will be transferred to column 3.

\subsubsection{Column Three (C3) Trona Pond}

This pond is used for normal trona crystallization at a specific gravity range of 1.235$1.26 \mathrm{~g} / \mathrm{cm}^{3}$.together with certain amount of $\mathrm{NaCl}$.

\subsubsection{Column Four (C4) Effluent Pond}

Crystallization of effluent salt is done in the specific gravity range of $1.26-1.31 \mathrm{~g} / \mathrm{cm}^{3}$. The effluent salt is highly soluble and contains sodium carbonate and sodium chloride ( 1:1 ratio).

\subsubsection{Column Five (C5) Trona Pond}

It is used for crystallization of normal trona which comes from the effluent salt. Since, the brine will still have some amount of sodium carbonate $( \pm \mathrm{NaCl})$, it is mandatory to change it into solution form by agitator machine and transfer the solution to the normal trona pond to recover trona and finally, $\mathrm{NaCl}$-rich water will be transferred to the salt pond to produce industrial salt. Detailed flow sheet of the improved processing procedure in the trona production as per new pond design is given in figure 6. 


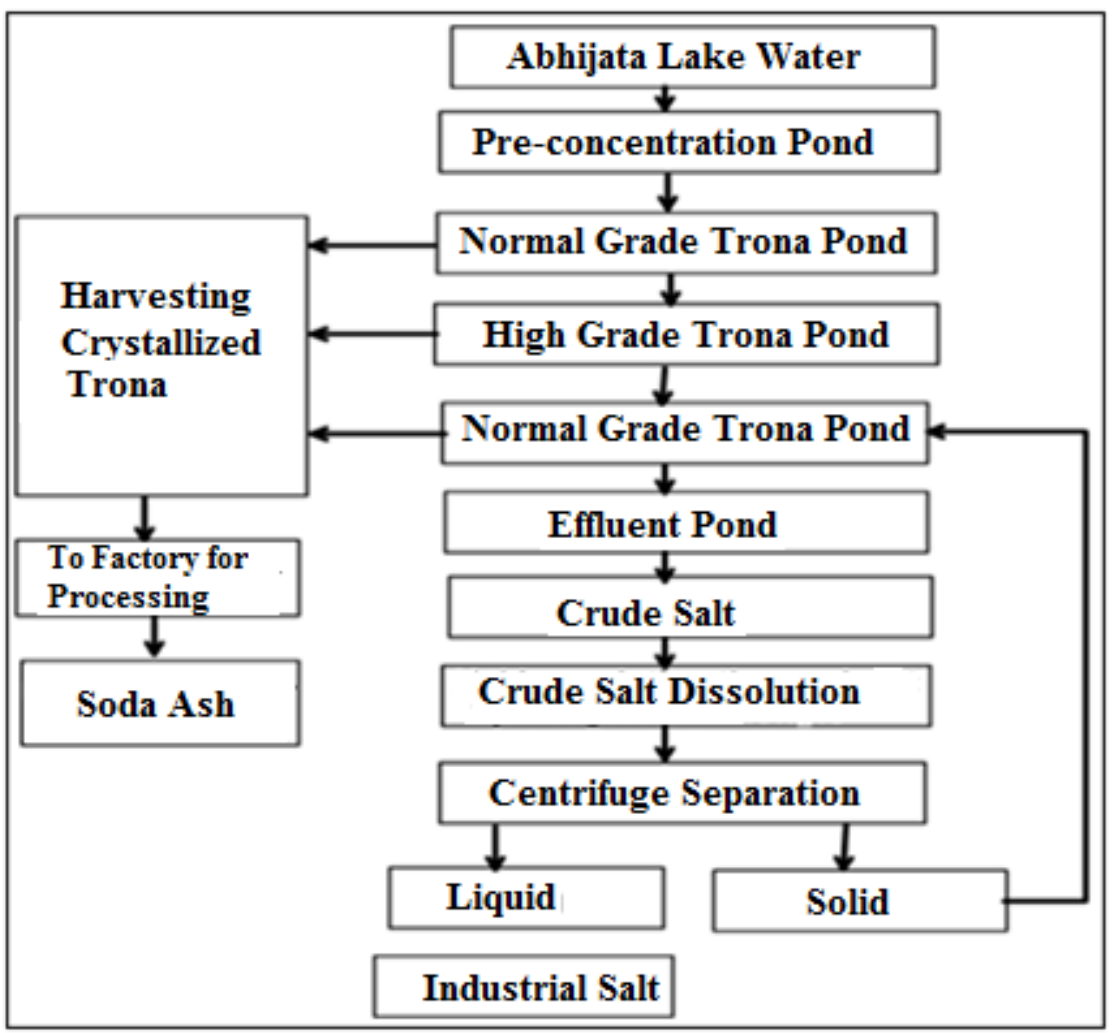

Figure 6. The improved flow sheet showing the procedure of trona and industrial salt production.

\section{CONCLUSION}

The study area (Central sector of MER) forms part of the Miocene rifting of East African Rift System and geologically dominated by lacustrine sediment, felsic (rhyolites, ignimbrites, unweldded tuff, and obsidians) and mafic volcanics. Abijata-Shala Soda Ash Share Company is producing about 5000t of soda ash per year, about $90 \%$ grade, against the proposed 1 million tons of soda ash of $97 \%$ grade. The rift tectonics-related structures are favoring development of lakes. Among different lakes, Abijata Lake water shows much higher values for sodium, carbonate and bicarbonate. Since felsic rocks are dominating the geology of the area, they seem to be contributing higher amounts of sodium to the rift lake waters. At present, only Abijata Lake water is being mined and used for soda ash production. The process involved is, transportation of Lake Water to the evaporation and crystallization ponds, transfer of brine water from one pond to another, collection of trona, and processing of trona.

The factors that are affecting quality and quantity of soda ash are, restriction of mining and production dry season; dilution of Lake water by spring water during transportation; leakage 
of Lake water through mud cracks in the channels; contamination of Lake water by dust and algae; and pond design related to crystallization of trona and timing of transfer of brine water from one pond to another.

Compared to other countries, Ethiopian soda ash contains relatively higher amounts of $\mathrm{NaCl}$. This is due to the timing of transfer of brine water from pre-concentration pond to trona pond; and from trona pond to effluent pond. It has direct effect on quality i.e. impurities remain if transferred early and $\mathrm{NaCl}$ is also crystallized if delayed. Keeping this in view, a new pond design is suggested by adding more ponds and re-arranging the transfer time in accordance with specific gravity and concentration of water. This will allow production of two types of trona, high quality trona with $\sim 97 \% \mathrm{Na}_{2} \mathrm{CO}_{3}$ and normal quality trona $\sim 90 \% \mathrm{Na}_{2} \mathrm{CO}_{3}$.

\section{ACKNOWLEDGEMENTS}

This paper forms part of MSc thesis and the financial assistance by Ministry of Education to conduct this research is duly acknowledged. The financial support provided in the form of recurrent budget project by College of Natural and Computational Sciences, Mekelle University is duly acknowledged. First author, B.G acknowledge the support extended by Dr. Berhanemeskel Made, Abijata-Shala Soda Ash Share Company, during field work and also permission to stay in the Company guest house during field work. Also B.G express his sincere thanks to Commissioner Asrat Bulbula, Senior Advisor of Shalla Soda Ash Project for his support and advice. B.G also extends his thanks to the company staff members especially Ato Getamesay, production and technical head; Ato Tadesse Belete, Trona production process division head; Ato Desalegn Mengstu, Quality control supervisor; and Ato Kahsay Amare for their help and encouragement during field work.

\section{REFERENCE}

Abijata-Shalla Soda Ash Share Company (ASSASCO). 2015. Report on the feasibility, production of soda ash.

Garrett, D.E. 1992. Natural Soda Ash- Occurrence, Processing and Use. New York, Van Nostrand Reinhold.

Geological Survey of Ethiopia. 2006. Geology and mineral resource of Ethiopia, 9:3-6

Metal Bulletin Ltd., London, 1980 
Meyer, W., Pilger, A., Rosler, A \& Stets, J. 1975. Tectonic evolution of the northern part of the Main Ethiopian Rift in southern Ethiopia. In: A. Pilger, A. Ro“sler (eds.), Afar Depression of Ethiopia. Inter-Union Commission on Geodynamics, Stuttgart. Science Report, 14:352-362.

Mohr, P.A.1971. The Geology of Ethiopia. University College of Addis Ababa press. Addis Ababa, Ethiopia.

Morton, W.H., Rex, D.C., Mitchell, J.G \& Mohr, P. 1979. Rift ward younging of volcanic units in the Addis Ababa region, Ethiopian Rift Valley. Nature, 280: 284-288.

Ralston, R. H., Hills, J. M \& Wood F. O. 2016. Common salt, sodium chloride and table salt.

Tahal Consultancy of Engineers Ltd. 1987. Feasibility study of sodium carbonate deposit in Abijata-Shalla lakes in main Ethiopian rift valley, Oromia, Central Ethiopia. Report. 